DOI: 10.37943/AITU.2021.16.52.006

\title{
H. Tanaka
}

PhD, Honorary Professor

hirojpmf@gmail.com,orcid.org/0000-0003-2631-721X

Kiev National University of Construction and Architecture, Ukraine

S. Bushuyev

Doctor of Technical Sciences, Professor, Head of Project

Management Chair

sbushuyev@ukr.net,orcid.org/0000-0002-7815-8129

Kyiv National University of Construction and Architecture, Ukraine

\section{PROJECT MANAGEMENT IN THE GLOBAL OIL AND GAS INDUSTRY BY CO-CREATING STRATEGIC VALUE FOR THE INDUSTRY}

\begin{abstract}
Project development and marketing on large oil and gas projects (LOGPs) by engineering-procurement-construction (EPC) contractors respond to massive capital investment (CAPEX) undertakings by oil and gas industry owners and takes on multi-lateral interactions carried out by a dozen actors proactively participating in the EPC contractors' business ecosystem created to remain competitive toward owner companies, which form of project marketing is different from a straight forward contractor - owner interaction found in the other branches of contracting industry. Most of such interactions are based on strategic trust among the relevant members built over decades of heavy win-win transactions.

This study has found the actors that compose the project development and marketing cycle in LOGPs, explored dominant logics of EPC contractor's project development and marketing, and analysed how primary actors in LOGP development and implementation co-create strategic values for both the respective corporations and sustainable overall industry growth.

The business ecosystem theory posits that a business ecosystem is an economic community supported by interacting organizations; the company holding a leadership role is valued by the community because it enables members to move toward shared visions to align their investments - this refers to the platform services theory and to find mutually supportive roles.

Key words: project development and marketing, large oil and gas projects (LOGP), strategic trust-based value co-creation, hard vehicle and soft vehicle of contractor competitiveness
\end{abstract}

\section{Background}

This study addresses project development and marketing by the tier-one global EPC (engineering, procurement, and construction) contractors operating in midstream-downstream, onshore oil and gas projects. The unit of analysis of this research is EPC contractors' project development and marketing of large oil and gas projects (hereafter referred to as LOGPs) amounting to US\$150 million and larger investment costs.

International Energy Agency' World Energy Outlook (IEA, 2015) estimated that the global oil and gas industry was expected to invest US\$25 trillion from 2015 to 2040 in development projects which stand at US\$ 1.02 trillion average per year. This expected oil and gas 
development investment volume has been drastically reduced in 2020 and 2021 due to two reasons: the drastically reduced demand for fuel caused by the prolonged COVID-19 Pandemic and accelerated global policy on energy transition by which oil and gas major companies have frozen a considerable part of oil and gas development spending (as of May 2021). Yet the fact that this industry is a typical capital-intensive industry remains unchanged. Although projects in the industry include also small and medium sized projects up to around US\$150 million, a salient characteristic therein resides in a relatively large number of LOGPs including mega projects exceeding one billion US\$ in investment costs. Merrow refers to mega projects in the oil and gas industry as those which are US\$ one billion and larger in terms of constantof-2003 \$ terms (Merrow, 2012). According to E\&Y report on mega oil and gas projects (E\&Y, 2016), 365 mega projects, here with US\$1 billion and larger costs too, were counted as of 2016.

As the most recent (2016) in-depth research on modeling success of large oil and gas projects, Redda (2016) defines large oil and gas projects (LOGP) in excess of US\$150 million. This study uses Redda's term LOGP to typically handle oil and gas capital investment projects which are frequently referred to as "CAPEX" projects as well.

This study addresses contractors' project development and marketing by the tier-one EPC contractors regularly or often occupying the top ten positions in Engineering News-Record's Top 100 International Contractors - EPC division published annually (ENR, 2018) who almost exclusively handle mega oil and gas projects (idem). Some authors in this literature review describe the LOGP EPC community as rather exclusive, dominated by few players on both owner side and tier-one contractor side, and forming an entrance barrier (Mohammad \& Price, 2006: Berends, 2007; Tanaka, 2014); this, however, is not a result of entrance barrier policy but owing to the natural law of the LOGP EPC business, e.g. the strictly high requirements of chemical plant technology, highly experienced and EPC specific technical personnel,and proactive project formation capability based on time-honoured stakeholder networking, all embodied in contractors' track records and reliability brand, that cannot be acquired in one decade or so. Also noted is that the EPC industry has a highly narrow allowance for errors in project management.

The literature review and EPC industry review indicate that the global oil and gas capital investment industry embraces a constellation of actors focusing on owners and EPC contractors, of which primary resources are dedicated to the industry over the past seven decades. This tradition has bonded the actors strongly, founded on the agency theory of B2B marketing (Banerjee et al. 2012), the convention of mutual rule setting and coordination (Thévenot. L, 2001), cross-fertilization and co-prospering ultimately directed the sound growth of the total capital investment industry; the author's analysis is that the project development and marketing on LOGPs is value co-creating (Vargo and Lusch, 2004) activities among echelons of actors in both a cascading direction with the prime EPC contractor at the top and the bottomup direction toward the owner company at the top.

The objectives of this study are to find the actors that compose the project development and marketing cycle in LOGPs, explore dominant logics of EPC contractor's project development and marketing, and analysed how primary actors in LOGP development and implementation co-create strategic values for both the respective corporations and sustainable industry overall growth on the foundation of strategic trust.

The main research question (MRQ) is: Is project development and marketing on large oil and gas projects (LOGPs) broad-ranging, multi-faceted, and highly structured interactions among the relevant capital investment industry members who co-create strategic values for, both the respective industry members and the industry overall? 


\section{Methodology}

This study is a qualitative and exploratory exercise to find the logic of project development and marketing on LOGPs and identify how it differs from project marketing in other contracting industry. This article is founded on a working paper "EPC project marketing in the global oil and gas industry - a constellation of stakeholders co-creating strategic value for both enterprises and sustainable industry overall growth: case study" submitted by the first author to EDEN Doctoral Seminar 2018 - Perspectives on Projects organised by SKEMA Business School on August $21^{\text {st }}$ to $23^{\text {rd }}, 2018$ in Lille, France (Tanaka, H., 2018).

The research is first founded on the author (Tanaka)'s employment experience in the global contractor side of the oil and gas industry for 42 years, with 20 relevant project management articles being published in a variety of ways, which provides us with an ethnographic lens for this study, and on review of 60 literature items on project development, project marketing, and other theoretical lenses, and oil and gas capital investment industry specific literatures and data in ten domains (idem).

On this theoretical foundation of the subject, we have conducted an analytical study for sense-making logics of project development and marketing on LOGPs by way of finding further evidence, secondary data and Web data such as analysis of tier-one EPC contractors' project news releases and profiling the recently completed and ongoing EPC joint venture LOGPS to construct the logic, and co-relating qualitatively the factors found to support the logics under construction.

The study has culminated in a conceptual model of project development and marketing for recommendation to the oil and gas capital investment industry and identified further research recommendations.

\section{Literature Review}

Construction Industry Institute (1994) published its extensive research on capital investment industry project development under the title of Pre-Project Planning which has now been renamed as Front-end Planning. Pre-project planning, or front-end planning, is defined as the process of developing sufficient strategic information with which owners can address risk and decide to commit resources to maximize the chances for a successful project. The process begins when a validated project concept has been identified during the business planning process and ends when a decision has been made whether or not to authorize funding for the execution of the project. The research has drawn three conclusions:

- Pre-project planning is an owner-driven process that must be tied closely to business goals.

- Pre-project planning is a complex process that must be adapted to the business needs of the owner company, tailored to specific projects, and applied consistently to all projects in order to gain full benefits.

- Corporate goals and guidelines for both pre-project planning and the project must be well-defined and aligned among project participants. Alignment requires involvement of operations, business, and project management early in the pre-project planning process.

The findings of the PPP research include influence and cost expenditure curves in Fig. 1.

The PPP study has revealed that many projects, both large and small, failed due to lack of careful planning in the upfront and warns it is too late that right project management of EPC is in place if against ill-defined or low-quality plans. The graph shows two curves based on research findings: one, from left bottom to right above is so-called cumulative capital expenditure curve; the other, from up left to right bottom is a curve representing roughly opportunity to influence project performance at a given progress point of the project (Bushuyev S., 2020, 2021). 


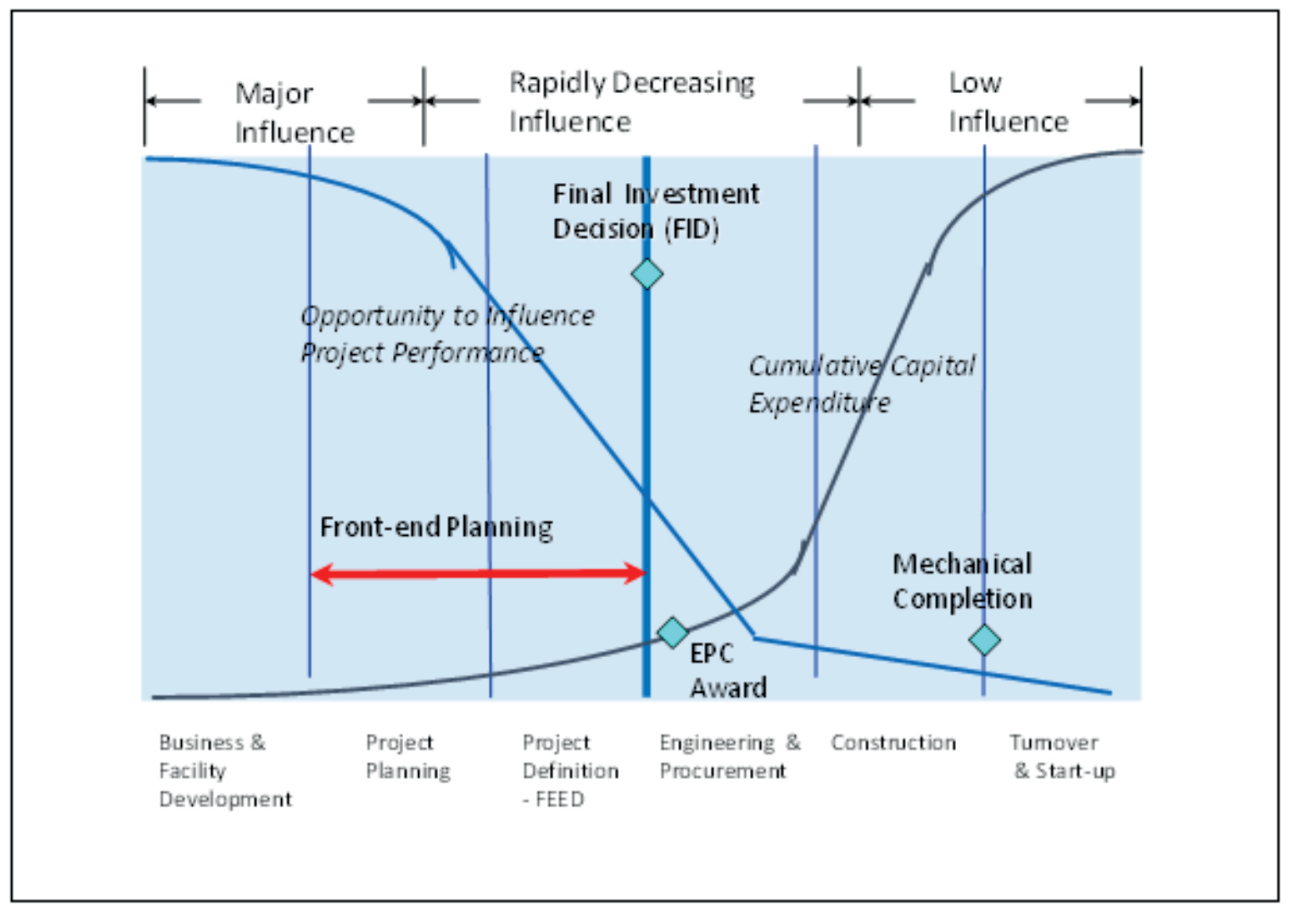

Fig. 1. Opportunity for Influence on Project Performance - Impact of Front-end Planning

The opportunity curve drops sharply toward the award of an EPC contract. The research suggests that $80 \%$ of the project performance is potentially determined within the $20 \%$ progress of the project in its entire cycle down to mechanical completion. Therefore, front-end planning prior to EPC is crucially important.

Later a graduate research by a middle manager of a European major oil company has been conducted on the correlation of the quality of front-end planning and overall project value realization (Hutchison \& Wabeke, 2006). The research used actual project data to demonstrate the value of front-end planning. The correlation is summarised in Fig. 2 . In the extreme right, projects surveyed are categorized into four. Clearly, projects which had good project definition coupled with good project execution is the best in project value realization, and the reverse, poor plus poor is the worst, and interestingly, projects having good definition but poor execution is much better in value realization than well executed but poorly defined projects.

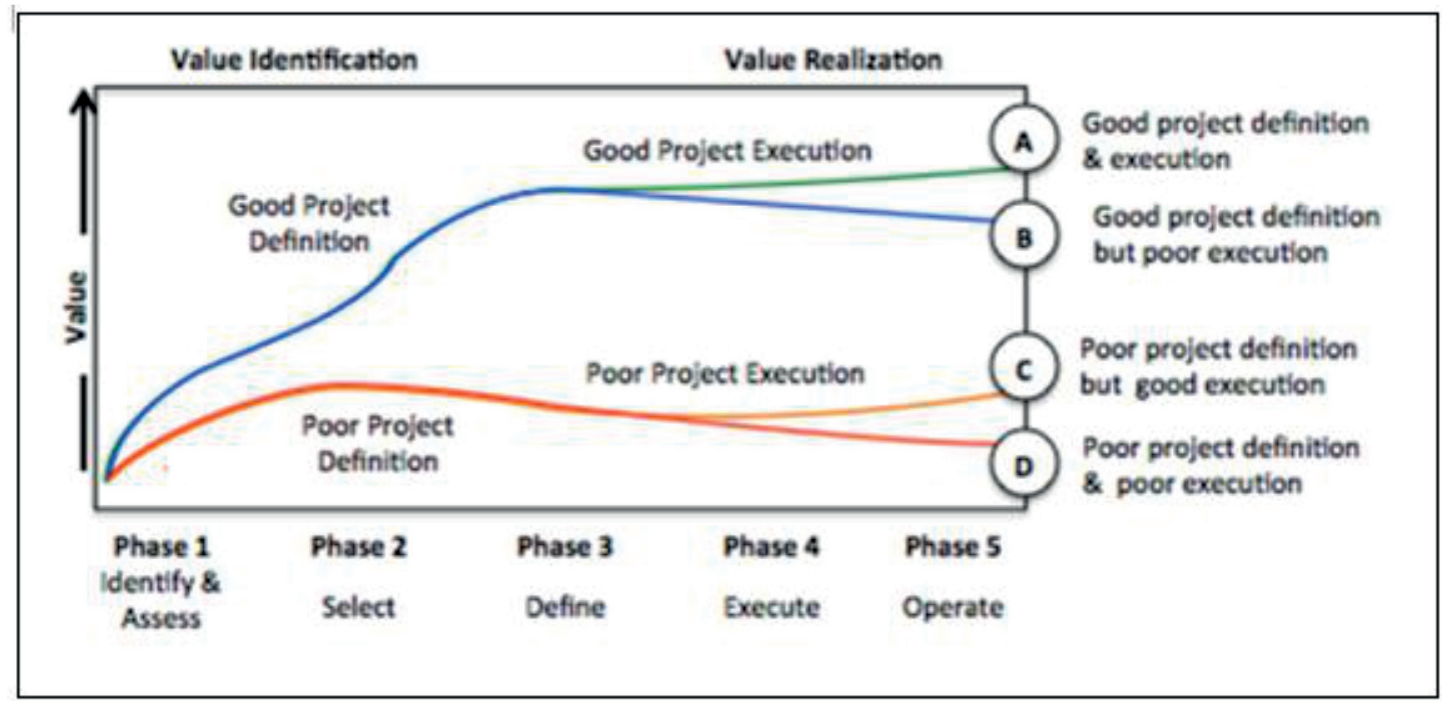

Fig. 2. Influence of Project Development Quality on the Value of a Project (after Hutchison \& Wabeke) 
Project marketing constitutes one school of the Nine Schools of Project Management proposed in "Perspectives in Projects" (Turner, J.R., Hueman, M., Anbari, F.T., \& Bredillet, C.N., 2010).

The marketing school argues that the various stakeholders of the project need to be persuaded to be part of the project and support its objectives and that the project marketing school, therefore, focuses on the interaction between stakeholders, alignment of strategic and tactical components, project advocacy, and customer relationship management. Project marketing elements include:

- Negotiating the fuzzy front-end

- Structuring the project solution

- Managing stakeholder relationships

- Identifying interrelationships of marketing and project management in specific types of projects

- Identifying and communicating value

- Creating and exchanging value

Project marketing researchers (Cova et al, 2002; Skaates \& Tikkanen, 2003; LecoeuvreSoudain \& Deshayes, 2006; and Blomquist \& Wilson, 2007) suggest that while project management deals with organizational and management issues, project marketing deals with sales and marketing issues of projects.

Project marketing focused on a customer-based approach helps build and maintain longlasting relationships with key clients avoiding short term opportunism. Cova et al (2002) proposed a three-stage model for project marketing: 1) independent of any project, 2) pretender, and 3) tender preparation.

According to this view, the goal of the project marketing process is to win the contract. However, project marketing is a continuous process that occurs during the realisation and project follow up phases as well. The follow up phase which occurs after the project has been delivered is very crucial since this determines client satisfaction, key account development, and its success will reduce the discontinuity of project activities (Lecoeuvre-Soudain, \& Deshayes, 2006; Cova et al, 2002). Vargo \& Lusch (2004) suggest the client gets no benefit until the output works. For this reason, Lecoeuvre-Soudain \& Deshayes (2006) added a fourth phase to the project marketing process, the post project phase, giving four phases of project marketing:

1) Pre-project marketing: The project does not exist yet, but the supplier anticipates the customer's requirements, develops themes for the potential bid, and maintains the relationship with the client.

2) Marketing at the start of the project: The supplier starts with co-construction of rules beside and within the network of influential relationships

3) Ongoing project marketing: The client and contractors proceed with re-negotiation, modifications, follow-up, and meetings following one another with constant relationship exchanges until the end of the project

4) Creating the conditions for future projects: The supplier maintains the relationship with the client, through logistics support and "sleeping relationships" which enables it to manage discontinuity in project business and prepare for future projects.

Lecoeuvre-Soudain \& Deshayes (2006) suggested that there are six foci of project marketing:

a. Relationship management (Rel)

b. Trust (Tru)

c. Collaboration (Col)

d. Communication (Com)

e. Training (Tra)

f. Going with (providing mentoring, coaching and support) (Gwi) 
Going with is identifying the customer's true requirement and working with the client to provide a solution to their requirement. Turner and Lecoeuvre (2017) take a perspective of the service dominant logic, (Vargo \& Lusch, 2004). The focus is on marketing with the client, collaborating with them to produce and sustain value for the client. The contractor collaborates with the client so that it can draw upon resources that contractor provides to:

- Co-create value networks and processes, (relationships)

- Co-create conversation and dialogue, (communication)

- Co-create value propositions, (collaboration)

- Co-create service offerings, (requiring trust).

Turner and Lecoeuvre (2017) argued that project marketing is a portfolio management.

Tikkanen, H., Kujala, J. and Artto, K. proposed The Four Portfolios Framework as a marketing strategy of a project-based firm (2007). The framework consists of the relationship portfolio management for the customer relationship portfolio and network relationship portfolio, and the project portfolio management comprising the sales and delivery project portfolio and the offering development project portfolio.

\section{Characterising the Oil and Gas Capital Investment Industry}

To profile the characteristics of the oil and gas capital investment industry which is the unit of analysis of this project development and marketing study, we have reviewed the articles of Yao and Ning (2002), Mohammad \& Price (2006), Berends (2007), Eweje (2012), Tanaka (2006b, 2014) and Redda (2016) who all are researchers belonging to or have come from the oil and gas industry. Eweje, Tanaka, and Redda's works are based, in turn, on other industry researchers' work on broad oil and gas industry artifacts. Initially 39 profiles were extracted from the article review, and selected 26 characteristic key words which were mentioned more than twice, were selected. The selected characteristics and density of agreement are shown in Table1.

Large oil and gas projects (LOGPs) are vehicles of corporate strategy implementation for oil and gas companies. Due to their cumulative huge investment costs (US\$1.1 trillion per year, as of 2015), LOGPs represent massive undertakings and require significant stretch of corporate resources, hence as a whole are an important economic activity. LOGPs require a dense focus on front-end works up to final investment decision (FID) lasting for a time period equalling to half of the EPC phase and, once sanctioned, span a long project cycle with the EPC phase taking four years or longer to complete. Mega grade LOGPs, in excess of US\$ one billion in investment costs, are mostly developed by owner joint ventures, and are implemented by plural EPC contractors, often forming an EPC joint venture(s), under multi-country sources of financing, located at a geographically challenging site, undertaken by globally dispersed EPC contractor teams, and operated by using project resources procured from throughout the world. Due to the huge size and CAPEX, a long period of time of existence, and global nature of project formation, LOGPs are exposed to changes in P.E.S.T.L.E. (political, economic, social, technological, legal, and environmental) factors and may exert significant political, economic, environmental, or social influence in the project host country.

Due to the interplay of all these important project development and execution factors, including phase overlaps, so many interfaces, activity interdependence, the project execution environment is highly complex and is exposed to all imaginable uncertainty and even by wicked risk (Kämpf, M et al., 2011). 
Table 1. Comparative review on characteristics of LOGPs

\begin{tabular}{|c|c|c|c|c|c|c|}
\hline Characteristics of Large Oil \& Gas Projects & 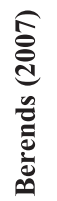 & 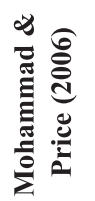 & 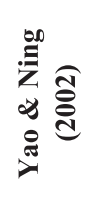 & 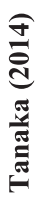 & 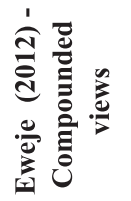 & 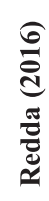 \\
\hline Vehicle of corporate strategy implementation & & & & & 0 & 0 \\
\hline Huge investment costs & 0 & 0 & & 0 & 0 & 0 \\
\hline Massive undertakings - scale, magnitude - an & 0 & 0 & & & 0 & \\
\hline Mostly multi-projects seen as a program & & & & 0 & 0 & \\
\hline Significant stretch on the corporate resources & & & & & $\mathrm{O}$ & \\
\hline Multiple sponsors or owner joint venture partners & & & & 0 & 0 & \\
\hline Multi contractors from multi countries & & & & 0 & 0 & \\
\hline EPC contractors playing a key role in the & 0 & & & & & 0 \\
\hline Long project lifecycle, usually over five years & 0 & & & 0 & 0 & 0 \\
\hline A significant number of stakeholders co-creating & 0 & & & 0 & 0 & 0 \\
\hline Significant challenge to the stakeholders & & & & 0 & 0 & \\
\hline Finance engineering & & & & 0 & 0 & 0 \\
\hline Higher levels of uncertainty/risk & 0 & 0 & & & 0 & \\
\hline Uncertainty in accurate prediction of desired & & & 0 & & & \\
\hline Uncertainty associated with long project period & 0 & & & 0 & & \\
\hline Exposure to shift in PESTLE factors & & & & 0 & & \\
\hline Risk of scope change or cancellation & & & & 0 & & \\
\hline Logistic challenges, especially on mega projects at & & & & 0 & 0 & \\
\hline High environmental risk & & & & 0 & 0 & \\
\hline Robust risk management & & & & 0 & 0 & \\
\hline High complexity - objectives, project organization & 0 & & 0 & 0 & 0 & 0 \\
\hline Dense focus on front-end works (up to final & & & & 0 & 0 & \\
\hline A challenging project location & & & & & 0 & \\
\hline Geographically dispersed teams & & & & 0 & & 0 \\
\hline \multicolumn{7}{|l|}{ An inadequate supply of resources } \\
\hline Multi vendors from multi countries & & & & $\mathrm{O}$ & & \\
\hline Spasmodic delivery/supply schedules & & 0 & & & & \\
\hline Work fragmentation & & & $\mathrm{O}$ & & & \\
\hline Tens of thousands on-site workforces from multi & & & & 0 & & \\
\hline \multicolumn{7}{|l|}{ Extensive infrastructure requirements } \\
\hline Higher technology, new or alternative technology & & 0 & & 0 & & \\
\hline Larger number of engineering disciplines (seven to & & 0 & & & & \\
\hline Socio-economic \& political interest in the host & & & & & 0 & \\
\hline Attention of NGO and the media & & & & & 0 & \\
\hline Significant political, economic, environmental, or & & & & & 0 & \\
\hline Difficult regulatory constraints & & & & & 0 & \\
\hline Direct and indirect impacts on the environment & & & & 0 & 0 & \\
\hline Direct and indirect socio-politico-economic & & & & 0 & 0 & 0 \\
\hline High level of corporate and public attention & & & & & 0 & 0 \\
\hline
\end{tabular}


EPC contractors play a key role in the development and implementation of LOGPs as project stakeholder formation, front end engineering design (FEED) defining the project, plant systems integration, plant technology integration, and project resources integration are all left to EPC contractors. Hence, they must master complexity and robust risk management.

\section{The Business Ecosystem for LOGPs}

The oil and gas capital investment project community, as seen from a prime EPC contractor, consists of such primary actors as the EPC prime contractor (ecosystem leader), the owner, EPC joint venture partner(s), ECA - export credit agency, large commercial banks, government agencies of the project export (contractor's home) country, government agencies of the host country, process technology suppliers, equipment \& materials vendors, construction subcontractors, and communities around the project site(s) (Tanaka, 2006a; 2006b).

The business ecosystem theory (Moore 1996) posits that a business ecosystem is an economic community supported by interacting organisations; the company holding a leadership role is valued by the community because it enables members to move toward shared visions to align their investments - this refers to the platform services theory (lansiti \& Levien, 2004)-, and to find mutually supportive roles. This theory very well explains the business domain of the EPC community for LOGPs in which in addition to the relationship with the owner, there are multi actor interactions for value co-creation founded on strategic trust - leverage theory (idem), namely, the EPC contractor and its business associates in plural directions - and dominant chains of eco system actors are tightly structured and connected so that substandard performance of one actor in the ecosystem can constitute a bottleneck in successful completion of an LOGP bottleneck theory (idem), eventual target of project marketing success and well-functioning or overall health (idem) of the oil and gas investment industry.

The roles of the respective actors of the ecosystem in terms of fulfilling functions in capital investment projects, degree that each actor's business is dedicated to the oil and gas industry and the type of impact of each actor's participation in capital investment projects as well as their positions in the EPC contractor's project marketing chain, are portrayed based on Tanaka (2006a) and general EPC industry practice, in Table 2.

Table 2. Actors in large oil \& gas capital investment projects marketing ecosystem

\begin{tabular}{|c|c|c|c|c|}
\hline Actor & $\begin{array}{l}\text { Function in capital } \\
\text { investment projects }\end{array}$ & $\begin{array}{c}\text { Degree of } \\
\text { dedication to the } \\
\text { oil \& gas industry }\end{array}$ & $\begin{array}{l}\text { Type of impact of } \\
\text { participation in capital } \\
\text { investment projects }\end{array}$ & $\begin{array}{c}\text { Position in EPC } \\
\text { contractor's } \\
\text { project marketing chain }\end{array}$ \\
\hline $\begin{array}{l}\text { EPC prime } \\
\text { contractor } \\
\text { (leader role in } \\
\text { the ecosystem) }\end{array}$ & $\begin{array}{l}\text { Provides professional } \\
\text { EPC services to the } \\
\text { owner to help realise } \\
\text { the owner's new } \\
\text { capital asset and soft } \\
\text { value }\end{array}$ & $\begin{array}{l}\text { Very high (it takes } \\
\text { other non-oil and } \\
\text { gas plants) }\end{array}$ & $\begin{array}{l}\text { As the agency theory } \\
\text { dominates, the primary } \\
\text { agent to perform the } \\
\text { project on behalf of } \\
\text { the owner }\end{array}$ & $\begin{array}{l}\text { Principal of project } \\
\text { development and } \\
\text { marketing on LOGPs }\end{array}$ \\
\hline Owner & $\begin{array}{l}\text { Invests and owns the } \\
\text { plant for additional } \\
\text { corporate capital value }\end{array}$ & Full & $\begin{array}{l}\text { Project not existent } \\
\text { without an owner }\end{array}$ & $\begin{array}{l}\text { Direct client of } \\
\text { contractor marketing }\end{array}$ \\
\hline $\begin{array}{l}\text { EPC joint } \\
\text { venture } \\
\text { partner(s) }\end{array}$ & $\begin{array}{l}\text { Provides, together with } \\
\text { the EPC contractor, } \\
\text { professional EPC } \\
\text { services to the owner } \\
\text { to help realise the } \\
\text { owner's new capital } \\
\text { and soft value }\end{array}$ & $\begin{array}{l}\text { Very high (it takes } \\
\text { other process plant } \\
\text { and infrastructure } \\
\text { projects as well) }\end{array}$ & $\begin{array}{l}\text { As the agency theory } \\
\text { dominates, the primary } \\
\text { agent, together with } \\
\text { the EPC contractor, to } \\
\text { perform the project on } \\
\text { behalf of the owner }\end{array}$ & $\begin{array}{l}\text { Partner of project } \\
\text { marketing to the EPC } \\
\text { contractor toward the } \\
\text { owner }\end{array}$ \\
\hline
\end{tabular}




\begin{tabular}{|c|c|c|c|c|}
\hline $\begin{array}{l}\text { Export credit } \\
\text { agency(s) } \\
\text { (ECAs) }\end{array}$ & $\begin{array}{l}\text { Provides government- } \\
\text { funded loan or covers } \\
\text { risks on project funds } \\
\text { provided by own } \\
\text { country's banks }\end{array}$ & $\begin{array}{l}\text { Very high due } \\
\text { to magnitude of } \\
\text { LOGPs }\end{array}$ & $\begin{array}{l}\text { Indispensable in most } \\
\text { of LOGPs in developing } \\
\text { and emerging } \\
\text { economies }\end{array}$ & $\begin{array}{l}\text { Where ECA loan is } \\
\text { prerequisite, decisive } \\
\text { enabler; } \\
\text { where not, maintain } \\
\text { "silent relationship" }\end{array}$ \\
\hline $\begin{array}{l}\text { Large } \\
\text { commercial } \\
\text { banks }\end{array}$ & $\begin{array}{l}\text { Provides project } \\
\text { loans as part of fund } \\
\text { required to build the } \\
\text { plant }\end{array}$ & $\begin{array}{l}\text { High at a bank } \\
\text { division in charge } \\
\text { of project finance }\end{array}$ & $\begin{array}{l}\text { Indispensable for all } \\
\text { mega projects and } \\
\text { most of LOGPs }\end{array}$ & Ditto \\
\hline $\begin{array}{l}\text { Government } \\
\text { agencies of the } \\
\text { project export } \\
\text { (contractor) } \\
\text { country }\end{array}$ & $\begin{array}{l}\text { Supports own country's } \\
\text { prime contractor and } \\
\text { ECAs }\end{array}$ & $\begin{array}{l}\text { Part of important } \\
\text { national industry } \\
\text { promotion policies }\end{array}$ & $\begin{array}{l}\text { Impact varies with } \\
\text { type of government } \\
\text { involvement; high } \\
\text { where ECA loan is } \\
\text { provided }\end{array}$ & $\begin{array}{l}\text { Facilitator in the } \\
\text { backyard of EPC } \\
\text { contractor's project } \\
\text { development and } \\
\text { marketing }\end{array}$ \\
\hline $\begin{array}{l}\text { Government } \\
\text { agencies of the } \\
\text { project host } \\
\text { country }\end{array}$ & $\begin{array}{l}\text { Provides government } \\
\text { permits to construct } \\
\text { the plant; supports } \\
\text { the owner company in } \\
\text { financing transactions } \\
\text { with foreign ECA(s) }\end{array}$ & $\begin{array}{l}\text { Part of important } \\
\text { national industry } \\
\text { promotion policies }\end{array}$ & $\begin{array}{l}\text { Impact varies with } \\
\text { type of government } \\
\text { involvement; high } \\
\text { where sovereign } \\
\text { guarantee is needed } \\
\text { for loan repayment }\end{array}$ & $\begin{array}{l}\text { Regulatory agency } \\
\text { that affects post- } \\
\text { contract award project } \\
\text { marketing }\end{array}$ \\
\hline $\begin{array}{l}\text { Technology } \\
\text { suppliers }\end{array}$ & $\begin{array}{l}\text { Provides process } \\
\text { technology for the } \\
\text { plant }\end{array}$ & $\begin{array}{l}\text { Full (specialized in } \\
\text { oil and gas) }\end{array}$ & $\begin{array}{l}\text { Except for open } \\
\text { art technology, } \\
\text { high but there is } \\
\text { alternation among like } \\
\text { technologies exists }\end{array}$ & Facilitator of marketing \\
\hline Vendors & $\begin{array}{l}\text { Supplies to the EPC } \\
\text { contractor equipment, } \\
\text { machinery or materials }\end{array}$ & $\begin{array}{l}\text { Very high (oil \& } \\
\text { gas vendors are } \\
\text { almost fenced) }\end{array}$ & $\begin{array}{l}\text { Indispensable } \\
\text { as function but } \\
\text { alternation among } \\
\text { vendors exists }\end{array}$ & $\begin{array}{l}\text { Enabler in tender } \\
\text { preparation stage } \\
\text { (competitive quotes) \& } \\
\text { EPC phase }\end{array}$ \\
\hline $\begin{array}{l}\text { Construction } \\
\text { subcontractors }\end{array}$ & $\begin{array}{l}\text { Supplies construction } \\
\text { services to EPC } \\
\text { contractor }\end{array}$ & $\begin{array}{l}\text { High except civil } \\
\text { and building } \\
\text { subcontractors }\end{array}$ & $\begin{array}{l}\text { Indispensable but } \\
\text { alternation among } \\
\text { subcontractors exists }\end{array}$ & Ditto \\
\hline $\begin{array}{l}\text { Communities } \\
\text { around the } \\
\text { project site(s). }\end{array}$ & $\begin{array}{l}\text { Provides community } \\
\text { support to project } \\
\text { construction or affect } \\
\text { construction in a } \\
\text { variety of way }\end{array}$ & $\mathrm{N} / \mathrm{A}$ & $\begin{array}{l}\text { May defer start, } \\
\text { obstruct or crush } \\
\text { construction; } \\
\text { conversely protects the } \\
\text { site project for smooth } \\
\text { construction execution }\end{array}$ & $\begin{array}{l}\text { Maintains silent } \\
\text { relationship during } \\
\text { bid preparation } \\
\text { and a possibly } \\
\text { communicate with } \\
\text { during site operation } \\
\text { phase on community } \\
\text { sustainability }\end{array}$ \\
\hline
\end{tabular}

Lecoeuvre-Soudain \& Deshayes (2006) proposed six foci to measure dependency and relationship between the actors in project marketing. They are Relationship management (Rel), Trust (Tru), Collaboration (Col), Communication (Com), Training (Tra), and Going with (providing mentoring, coaching and support) (Gwi). Considering that the EPC contractor's project development and marketing for LOGPs is not just enabled by the bilateral marketing relationship between the contractor and the owner - for instance, a LOGP is not materialized by a contractor not having access to an ECA; many of LOGPs need technology licensor(s)' participation in the project; mega projects pricing US\$1 billion and larger need a joint venture EPC partner (s) who are otherwise competitors; EPC bid competitiveness depends on quotation competitiveness of major equipment vendors and core construction subcontractors founded on multi-lateral marketing relationship, the authors have analysed the relationship between the 11 actors in the EPC contractor's ecosystem posited above as depicted in Table 3. 
Table 3. Matrix of project marketing relationships among the actors of LOGP.

\begin{tabular}{|c|c|c|c|c|c|c|c|c|c|c|c|}
\hline & Contractor & Owner & JV Partner & ECA & Banks & Govt. - Exp & Govt. - Host & Technology & Vendors & Subcontr. & Community \\
\hline EPC Contractor & & Tru & Col, Tru & Col, Tru & Col, Tru & Col, Tru & \begin{tabular}{|c|} 
Rel \\
\end{tabular} & Col & Col & Col (Tra) & Com \\
\hline Owner & Tru & & Tru & Rel & Rel. & Rel. & Rel & Col or Rel & N/A & N/A & Com \\
\hline EPC JV Partner & Tru & Col, Tru & & Col, Tru & Col, Tru & Col, Tru & Rel & Col & Col & Col (Tra) & Com \\
\hline ECA & Rel & Col, Tru & N/A & & Col, Tru & Col, Tru & Rel & N/A & N/A & N/A & N/A \\
\hline Comm. Banks & Rel & Col, Tru & & Col, Tru & & Col, Tru & Rel & N/A & N/A & N/A & N/A \\
\hline Govt. - Export Ctr. & Rel & Col,Tru & N/A & Col, Tru & Com & & Col & N/A & N/A & N/A & N/A \\
\hline Govt. - Host Ctr. & Col, Tru & Rel & Col & Rel & Com & Col & & N/A & N/A & N/A & N/A \\
\hline Technology Supplie & Rel & Col & Col & N/A & N/A & N/A & N/A & & N/A & N/A & N/A \\
\hline Vendors & N/A & Col & Col & N/A & N/A & N/A & N/A & N/A & & Com & N/A \\
\hline Subcontractors & Com & Col & Col & N/A & N/A & N/A & Com & N/A & Com & & Com \\
\hline Site Community & Rel & Com, (Tra) & Com & N/A & N/A & N/A & Com & N/A & N/A & Com, (Col) & \\
\hline
\end{tabular}

Project Marketing Foci Code after Lecoeuvre-Soudain \& Deshayes (2006)

1. Relationship management (Rel)

2. Trust (Tru)

3. Collaboration (Col)

4. Communication (Com)

5. Training (Tra)

6. Going with (providing mentoring, coaching and support) (Gwi)

Those relations labelled as "Tru" (trust) or "Col (collaboration)" are considered as most critical from the viewpoint of the first stage of the project developing and marketing success, or wining an EPC contract. Those relations are the EPC contractor's transaction/relation with the owner, joint venture partner (an EPC contractor ally), export credit agency (ECA), commercial banks joining a syndicated loan with the ECA and the government agency (s) of plant exporting country.

\section{The Project Development and Marketing Practice on Large Oil and Gas Projects}

The first questions that we should ask regarding the practice of project development and marketing by the EPC contractor for LOGPs is: what are the phases of a LOGP as seen from the owner's project lifecycle, and how does the EPC contractor's project development and marketing activities fit in in the owner's cycle of project development, implementation and post-completion commercial operation?.

Tanaka (2006b, 2014), Eweje (2012) and Merrow (2012) described the phases of an LOGP all from the owner's cycle. The three authors used slightly different nomenclatures but phasing is basically same. Fig. 3 delineates Tanaka's LOGP phases and density of project marketing effort on both the EPC contractor side and the Owner side; the density scale is for the image.

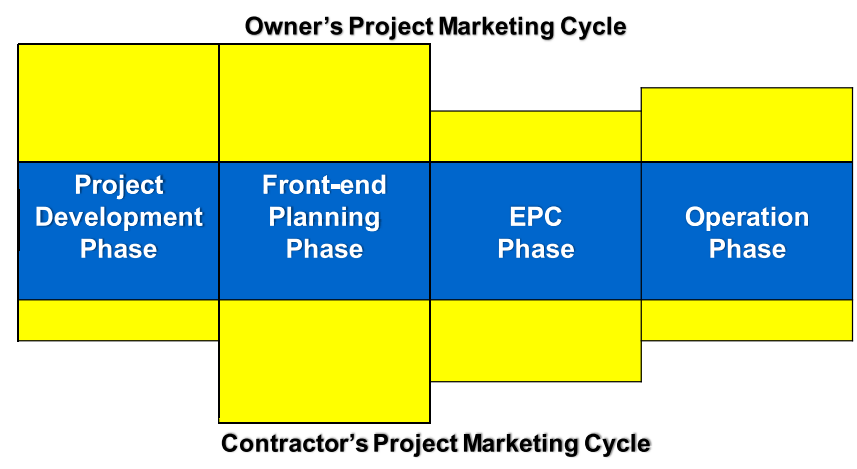

Fig. 3. Project phases and project marketing density cycle.

Tanaka (2006) described the four phases and the authors have analysed the EPC contractor's project marketing in the respective phase as follows (Tanji, N., Tanaka, H. and Bushuyev S. (2014). 
The Project Development Phase aims at project conception as business and strategic analysis of the project value. During this phase, an owner carries out basic data gathering, project need screening against the corporation's business strategy, and evaluating basic conditions for materializing the potential project. This phase is basically conducted confidentially by the owner and the contractor's project marketing function endeavours to sense some sort of project smell. The Front-end Planning Phase is a preamble to project execution and is intended to explore detailed feasibility and later definition of the project, culminating with final investment decision (FID) or withdrawal, or postponement of the investment decision. Project definition work, referred to as front-end engineering design (FEED) in the second half of this phase, is usually undertaken with the owner employing a global EPC contractor. Obviously, the EPC contractor (s) who performs FEED work would be in a considerably favourable position in the bidding to the EPC work coming thereafter. The EPC bidding takes place after the completion of FEED and contractors' all out efforts are expended for proposal success. The Project Execution Phase is most frequently called the EPC Phase. As the phase term indicates, engineering, procurement of equipment and materials to compose the plant and site construction of the plant is carried out with project management directing and integrating total project efforts. The successful completion of the project is the most eloquent vehicle of project marketing for the contractor company and the contractor makes all required efforts to complete the project according to prime contract terms. The Operation and Maintenance Phase on the plant completed is the owner's responsibility. However, the EPC contractor stands by for the owner's call on any problems and difficulty on the plant according to warranty clauses, or 'trust' relationship for a year or two. All these post plant completion relationship with the owner provides a vital source of marketing for a future new contract to the contractor.

There is a match of the EPC contractor's project development and marketing efforts on this oil and gas industry specific context of project lifecycle to the four-stage view of the project marketing life-cycle proposed by Er, et al. (2019) in that in 1), Pre-receipt of invitation to tender: all the major EPC contractors maintain early marketing coverage of the market or potential market countries; it provides a feasibility study, a key ground work for project development for the owner, as a separate contract; and conduct front end engineering design (FEED) to firm project definition on behalf of the owner on all the LOGPs; in 2), Tender preparation and contract negotiation: this is core of the EPC contractor's project marketing efforts, consuming 10 to $15 \%$ of available person-hours (undisclosed industry data) of a contractor; in 3), Project delivery: this cycle is a mainstay business of the EPC contractor company; and in 4), Post project: as discussed earlier, contractors consider this as a valuable opportunity for marketing for new contracts.

Assuming that EPC contractors' primary success is wining contracts, we have collected survey results and have done an additional survey on owners' contractor proposal evaluation criteria or contractor self-evaluated proposal success factors. The tabulated results are given in Table 4.

The surveys searched are U.S.A. consulting company Transmar Consult's owner survey on contactor evaluation criteria cited in Oil and Gas Journal June 14, 2003 issue (Oil and Gas Journal, 2003) from 1995 to 2005; U.S.A. owner and contractor, and Japanese contractor surveys on contractor evaluation criteria in 2004, originally conducted by Construction Industry Institute and Ministry of Economy, Trade and Industry of Japan, respectively (Tanaka, 2006a), and analysis of tier-one EPC contractors (two USA, two Japanese and one European)' news releases on new projects on LOGPs constituted by 228 projects from 2009 to the first quarter of 2018, conducted by the first author.

The evaluation criteria are compounded from the four sources of survey. Those ranked in the top three are shown in bold letters. The tabulation indicates that the ranking is considerably consistent among the same survey (series) but is not so much among the surveys. 
Table 4. Tabulated results of multi-source surveys on evaluation criteria ranking for EPC contractors' proposals

\begin{tabular}{|c|c|c|c|c|c|c|c|c|c|}
\hline & $\begin{array}{c}2018 \text { EPC } \\
\text { Contractor Web } \\
\text { survey }\end{array}$ & \multicolumn{3}{|c|}{2004 US/Japan Survey } & \multicolumn{5}{|c|}{$\begin{array}{c}\text { Transmar Consult Survey (cited in Oil \& Gas Journal, July 2003) } \\
\text { Owners only }\end{array}$} \\
\hline & $\begin{array}{c}2 \text { USA, } 2 \text { Japanese, } \\
1 \text { European co's. }\end{array}$ & US Owner & $\begin{array}{c}\text { US } \\
\text { Contractor }\end{array}$ & $\begin{array}{c}\text { Japan } \\
\text { Contractor }\end{array}$ & 2005 & 2003 & 2001 & 1997 & 1995 \\
\hline \multirow{2}{*}{ Contractor Proposal Evaluation Criteria } & \multicolumn{9}{|c|}{ Total number key words asked for ranking } \\
\hline & 11 & 7 & 7 & 5 & \multicolumn{5}{|c|}{17 (selected top 10) } \\
\hline Project Management Capability & 9 & $\mathrm{~N} / \mathrm{A}$ & 1 & 3 & 2 & 1 & 2 & 2 & 2 \\
\hline Contractors' Price / Commercial Terms & $\begin{array}{l}\text { Not mentioned as } \\
\text { self-explanatory }\end{array}$ & 18.3 & 3 & $2 \& 5$ & 5 & 2 & 3 & 3 & 6 \\
\hline Quality of Contractor Key Personnel & $\begin{array}{l}\text { included in } \\
\text { Experience }\end{array}$ & N/A & 2 & 1 & 1 & 3 & 1 & 1 & 1 \\
\hline Project Control Systems & $\begin{array}{c}\text { included in Project } \\
\text { Management }\end{array}$ & N/A & N/A & N/A & 7 & 4 & 4 & 8 & 3 \\
\hline Detailed Engineering Capability & $\begin{array}{l}\text { included in } \\
\text { Experience }\end{array}$ & N/A & N/A & N/A & 4 & 5 & 6 & 10 & 5 \\
\hline Construction Capability & $\begin{array}{l}\text { included in } \\
\text { Experience }\end{array}$ & N/A & N/A & N/A & 3 & 6 & 8 & 5 & 7 \\
\hline Experience with Similar Work & 1 & N/A & N/A & N/A & 6 & 7 & 5 & 7 & 8 \\
\hline Experience with Same Client & 3 & N/A & N/A & N/A & N/A & N/A & N/A & N/A & N/A \\
\hline Experience with Same Geographic Are & 2 & $\mathrm{~N} / \mathrm{A}$ & N/A & $\mathrm{N} / \mathrm{A}$ & 8 & 8 & 7 & 9 & 10 \\
\hline Responsiveness \& Flexibility & N/A & N/A & N/A & N/A & 11 & 9 & 10 & 6 & 4 \\
\hline Safety Performance & N/A (self-explanatory & 2 & & 4 & $N / A$ & N/A & N/A & N/A & N/A \\
\hline Shorter Delivery Time & 10 & N/A & N/A & N/A & \multicolumn{5}{|c|}{ Included in Project Control Systems } \\
\hline Joint Venture Strength & 5 & $\mathrm{~N} / \mathrm{A}$ & N/A & N/A & N/A & N/A & N/A & N/A & N/A \\
\hline High engineering capability, Innovative solution & 4 & N/A & N/A & N/A & N/A & N/A & N/A & N/A & N/A \\
\hline
\end{tabular}

This is judged to have been caused by differences in the purposes of asking questions, differences in given criteria to rank, and differences in time surveys were conducted. Nevertheless, contractor's price is one of the top-ranked, and those criteria related to the contractor's structural capability (hard marketing vehicle), e.g. quality of contractor key personnel, project management capability, and experience in the same plant, same geographical area (country) and same client, were ranked in the upper side. Joint venture strength, which is the typical soft vehicle of project development and marketing, is found only in the 2018 contractor new project releases survey; the background is that news releases pertain to the five global tierone contractors and they are active players of mega projects and use the JV delivery method quite ordinarily. From the argument of the rest of this article, it is obvious that the contractor's price (as marketing strength) is a result of a balanced combination of the structural capability, or the author-labelled hard marketing vehicle and the EPC contractor's business ecosystem constructing ability, the soft marketing vehicle.

As analysed from the characterisation and cycle of project marketing discussed above, we have extracted five dominant logics of the EPC contractor's project development and marketing for LOGPs.

\section{Logic 1: Mastering characterization of the complex, dynamic and risky market}

As reviewed in Section 4, LOGP project development and execution are exposed to all imaginable uncertainty and even wicked risk, including changes in P.E.S.T.L.E. factors. As the 
EPC contractor plays a key role in the development and implementation of LOGPs, e.g. project implementation scheme formation, front end engineering design (FEED) defining the project, plant systems integration, plant technology integration, and project resources integration are all left to EPC contractors, the EPC contractor must have structured risk identification and mitigation capabilities toward the EPC ecosystem being built and the project exterior environment. The contractor's proposal naturally must have incorporated risk responses.

\section{Logic 2: Building consistently the EPC contractor's structural capability}

The EPC contractor's sufficiency of structural capability (Cova \& Salle, 2007), labelled as SSC, comprehends volume of contracting business and financial stability, track record on the same type of the plant, the same client and the same country, safety, security, health and environment (SSH\&E) policy, project execution and management capability demonstrated from past projects as well as proposed for a particular project, access to an export credit agency and to large commercial banks investing in projects and having a robust network with equipment suppliers and construction subcontractors throughout the world (ENAA, 1996). SSC can only be built by decades of painstaking practice and successful delivery of LOGPs and proven mutually beneficially transactions between the owner and the EPC contractor.

Logic 3: Constructing proactively the EPC contractor's ecosystem for a specific LOGP

EPC contractors form a project specific business ecosystem (Moore, 1996; Insati \& Levin, 2004) and fulfil the leader role in extracting proper value of the respective ecosystem players and co-create overall value for the relevant EPC project with the owner company since LOGPs are vehicles of corporate strategy implementation for oil and gas companies, e.g. ability to deliver projects for superior cash-flow, operational excellence, increased production via projects, maximising resource and asset value, maximising value-chain returns, demonstrated technological innovation (Tanaka, 2006a; Tanaka, 2006b; Eweje, 2012: Redda, 2016).

Project development and marketing on LOGPs is no longer the mere transaction between an EPC contractor and an owner. Project marketing is multi-faceted and time-consuming potential value co-creation activities as discussed in Section 5. Construct of the EPC contractor ecosystem is core of the soft vehicle of LOGP marketing.

\section{Logic 4: Holding a deeper insight into total project development and marketing success on LOGPs}

Successful project development and marketing for LOGPs is total project cycle efforts for the EPC contractors and is expressed as Layer 1 (in the bottom) Sufficiency of structural capabilities (SSC); Layer 2 Success of proposal (SPR); Layer 3 Success of project output (SPOP), and Layer 4 Success of project outcome (SPOC). SSC is argued in Logic 2. Winning a contract (SPR) endows the EPC contractor with an opportunity to complete the project on behalf of the owner thereby attaining the contractor's direct business objectives. Delivering the EPC project (SPOP) meeting the contract conditions, marks the EPC contractor's success of services, reinforcing its portfolio of contractor track record. When the owner has achieved project outcome, or strategic goals embodied in the project, it would ferment deeper trust in the EPC contractor who has engineered and built the plant. Maintaining responsive post-project completion relationship with the owner is highly important.

\section{Logic 5: Following a structured path to LOGP EPC contract award}

The oil and gas capital investment industry is a mature industry which has proven business practices, formality of owner-contractor relationship, and market segmentation by sizes of projects. On the assumption that tier-one EPC contractors can evenly complete the LOGP, marketing competition should eventually focus on cost offerings as owners say that owners' evaluation criteria of contractor proposals is for the lowest conditioned (and qualified) price (undisclosed international oil company, 1996). All the pre-EPC marketing efforts should be concentrated to hammering out a competitive price while allowing for project risk. One 
acceleration route to LOGP award is to secure a front-end engineering design (FEED) contract defining the project definition for the owner to seek final investment decision (FID) and as basis of EPC bidding.

As argued by Tikkanen et al. (2006) and posited by Turner \& Lecoeuvre (2016), we have affirmed that the project development and marketing for LOGPs is part of portfolio management.

\section{New EPC Contract Strategy and Its Impact on Project Marketing}

Mohammad and Price (2004) discussed the arrival of innovative contract procurement strategies; Turner (2007) introduced partnering in projects whereby the owner and the contractor work together in a spirit (and in a contractual arrangement) of partnership, whereby they cooperate to achieve a mutually beneficial outcome; and Tanaka (2006b) enumerated strategic alliance between the owner and contractor operating in an amalgamated project organization format for totally shared work, profit and loss, and liability; partnering; unincorporated joint ventures (JVs) of EPC contractors who share the totality of project work, profit and loss and liability as new forms of LOGP EPC delivery.

According to the analysis of 228 web-based new project releases for the past ten years up to the first quarter of 2018 issued by the two USA, two Japanese and one European tier-one contractors, conducted by the first author (Tanaka, 2018), an absolute majority of recently completed and ongoing LNG and refinery projects have used or are using the JV format, there are 11 cases of partnering, but strategic alliance, often found in the 1990's, has not exited over the past ten year up to 2018. It can be inferred that the EPC contractor should market the project to its targeted EPC contractor partner before doing it to the owner and that partnering requires higher "trust" (Lecoeuvre-Soudain, L. \& Deshayes, P., 2006).

In facing the 'existential crisis' of capital programme delivery (European Construction Institute, 2018), however, closer owner and contractor alignment is voiced (idem) and there has occurred an industry initiative to renovate the structures of capital program (FEED + EPC) delivery for reducing transaction costs in the EPC chain (Construction Industry Institute, 2018). There is situational evidence to favour the JV EPC format and partnering but no hard data to substantiate the benefit is available yet. The Possible impact on project marketing by the emerging initiative of re-structuring the capital program is not known yet; it should take years before any effect is found.

\section{Conclusion and Further Research Recommendation}

The findings of this research have responded to the main research question (MRO) all positively in Sections 4 to 7. Project development and marketing of LOGP:

- depends on multi-faced and highly structured interactions among the capital investment industry members which is based on strategic trust; such relationship is represented by an EPC business ecosystem; and

- The EPC business ecosystem co-creates strategic values for, both the respective industry members and the industry overall.

In conclusion, we propose the model of LOGP project development and marketing.

The EPC contractor's project development and marketing for LOGPs is founded on both, a hard vehicle and a soft vehicle as depicted in Fig. 4.

The hard vehicle represents the EPC contractor's structural capability comprehending global level business volume and financial stability; track records on plants, clients and project host countries; structural services efficiency and project completion reliability - this is the EPC contractor's brand based on past hard achievement; access to financing institutions for arranging for financing; and the capability to perform front-end engineering design (FEED) on 
behalf of the owner which basic designs the plant and defines other key parameters of the project enabling the owner to make final investment decision (FID).

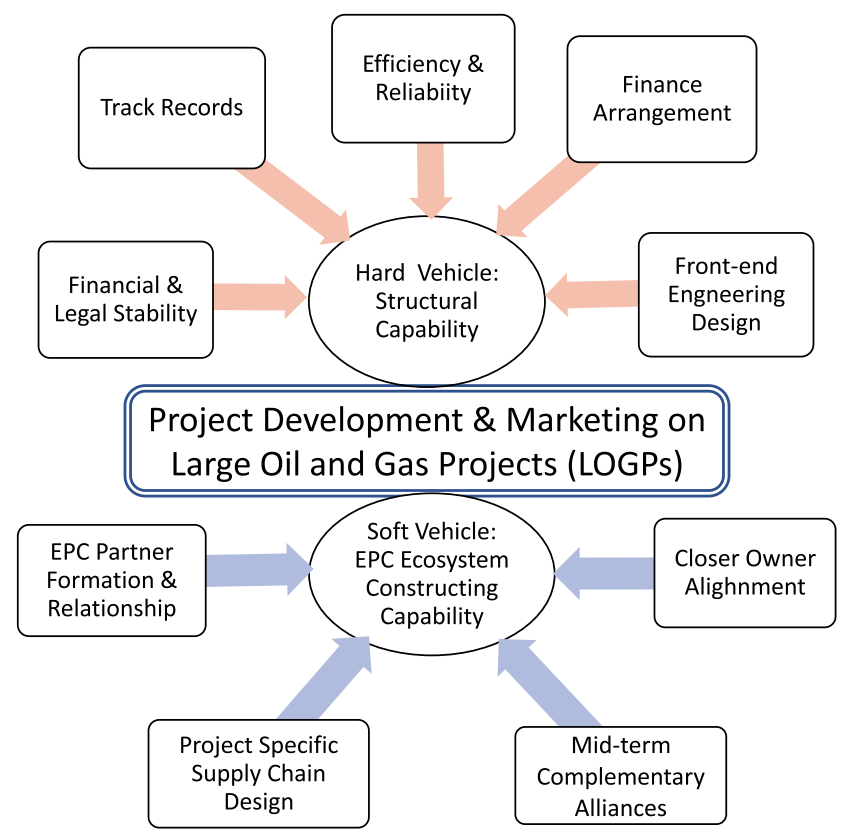

Fig. 4. EPC contractor's project development and marketing model for LOGPs.

The soft vehicle concerns variable marketing elements which all depend on strength of strategic trust, and can be represented as the EPC contactor's business ecosystem construct for a specific LOGP. The soft vehicle develops and maintains mutually beneficially collaborative relationships with a small number of industry colleague EPC contractors, and for each project, selects a partner during a pre-proposal phase to win a bid; designs a supply chain of detailed design centres, plant component vendors, and services/construction subcontractors out of the registered vendor and subcontractor lists; find and conclude mid-term business alliance agreements with EPC contractors and/or fabricators who have demonstrated strength in certain expertise; and collaborate with owners on plant technology innovation and initiatives for transaction (supply chain) cost reduction for the sound existence of the EPC industry - this is an investment for the future.

The research has been conducted based on literature review, analysis of existing, time series of industrial research data, and authors' additional data collection by way of web analysis. As the secondary data accessed were contributed by researchers in the EPC industry mostly as part of industry research institutes' funded research, the authors feel the confidence level is considerably high. Yet, as the EPC industry is moving quite fast in struggling with the volatility of the market and ever-increasing sizes and complexity of LOGPs, it would be worthwhile organising a more structured research on this subject by accessing top-level practitioners of project marketing and project management on both the EPC contractors side and the owners' side, and preferably senior staff of EPC industry research institutes.

\section{References}

1. Berends, K. (2007). Engineering and construction projects for oil and gas processing facilities: Contracting, uncertainty and the economics of information. Energy Policy, 35(8), 4260-4270.

2. Banerjee, R., Bergen, M., Dutta, S., \& Ray, S. (2012). Applications of agency theory in B2B marketing: review and future directions. Handbook of business-to-business marketing. 
3. Blomquist, T., \& Wilson, T. L. (2007). Project marketing in multi-project organizations: A comparison of IS/IT and engineering firms. Industrial Marketing Management, 36(2), 206-218.

4. Construction Industry Institute (CII). (1994). Pre-project planning: Beginning a project the right way. Research Summary.

5. Construction Industry Institute (CII). (2018). "OPERATING SYSTEM 2.0" unlocking project value. Research Summary. https://slideplayer.com/slide/14254402/.

6. Cova, B., Ghauri, P.N., \& Salle, R. (2002). Project marketing: beyond competitive bidding (No. hal02298023).

7. Cova, B., \& Salle, R. (2007). Introduction to the IMM special issue on 'Project marketing and the marketing of solutions' A comprehensive approach to project marketing and the marketing of solutions. Industrial Marketing Management, 36(2), 138-146.

8. Engineering Advancement Association of Japan - ENAA (1996). Research report on 'multi project management' at Japanese EPC companies (in Japanese: unpublished). Tokyo: Engineering Advancement Association of Japan

9. Engineering News-Record (2018). ENR's Top 100 International Contractors.

10. Turner, J.R., Lecoeuvre, L., Sankaran, S., \& Er, M. (2019). Marketing for the project: project marketing by the contractor. International Journal of Managing Projects in Business.

11. Ernst and Young (2016) Spotlight on oil \& gas mega projects: EYGM Limited

12. Kinsella, R., \& Kinsella, M. Austerity, Autonomy and Existential Crisis in the European Union.

13. Eweje,J.A. (2010). Investigating factors that affect project manager decisions on oil and gas megaprojects, and how they impact the realisation of strategic value (Doctoral dissertation, PhD thesis, Lille: SKEMA Business School).

14. Eweje, J., Turner, R., \& Müller, R. (2012). Maximizing strategic value from megaprojects: The influence of information-feed on decision-making by the project manager. International Journal of Project Management, 30(6), 639-651.

15. Iansiti, M., \& Levien, R. (2004). The keystone advantage: what the new dynamics of business ecosystems mean for strategy, innovation, and sustainability. Harvard Business Press.

16. Cozzi, L., \& Gould, T. (2015). World Energy Outlook 2015. Int. Energy Agency.

17. Kämpf, M., \& Haley, S. (2011). Risk management in the Arctic offshore: wicked problems require new paradigms.

18. Lecoeuvre-Soudain, L., \& Deshayes, P. (2006). From marketing to project management. Project Management Journal, 37(5), 103-112.

19. Merrow, E.W. (2012). Oil and gas industry megaprojects: Our recent track record. Oil and Gas Facilities, 1(02), 38-42.

20. Mohammad, M. F., \& Price,A. (2003). Procurement strategies for the oil and gas industry: conventional versus innovative approaches.

21. Moore, J.F. (1996). The Death of Competition. Leadership and Strategy in the Age of Business Ecosystems. NY, Harper Business.

22. Study: Project management capability key to selecting engineering contractors. (2003). Oil and Gas Journal

23. Redda, Y.T. (2016). Investigating and modelling the success of large oil and gas projects (unpublished doctoral thesis): SKEMA Business School, Lille, France.

24. Skaates, M.A., Tikkanen, H., \& Lindblom,J. (2002). Relationships and project marketing success.Journal of Business \& Industrial Marketing. https://doi.org/10.1108/08858620210439068

25. Tanaka, H. (2006). (2006). The Engineering and Construction Industry-A Mature Model for the Future of Project Management Success.

26. Tanaka, H. (2007). Cross-cultural project management on major-sized global oil and gas plant projects. DI Cleland \&.

27. Tanaka, H. (2014). Toward project and program management paradigm in the space of complexity: a case study of mega and complex oil and gas development and infrastructure projects. ProcediaSocial and Behavioral Sciences, 119, 65-74.

28. Tanaka, H. (2018). EPC project marketing in the global oil and gas industry - a constellation of stakeholders co-creating strategic value for both enterprises and sustainable industry overall growth: 
case study, working paper and summary presentation at Project Perspectives 2018 organized by European Institute for Advanced Studies in Management (EIASM) and SKEMA Business School: SKEMA Business School, Lille France

29. Tanji, N., Hiroshi, T., \& Bushuyev, S. (2014). Benchmarking the state-of-the-art information and communication technology (ICT) infrastructure supporting management of major-sized engineering and construction projects.

30. Thévenot, L. (2001). Organized complexity: conventions of coordination and the composition of economic arrangements. European journal of social theory, 4(4), 405-425.

31. Turner, J. R. (2006). Partnering in projects. Global Project Management Handbook: Planning, Organizing and Controlling International Projects: Planning, Organizing, and Controlling International Projects: Planning, Organizing, and Controlling International Projects.

32. Turner, R. J., Huemann, M., Anbari, F. T., \& Bredillet, C. N. (2010). Perspectives on projects. Routledge.

33. Turner, J. R., \& Lecoeuvre, L. (2017). Marketing by, for and of the project: project marketing by three types of organizations. International Journal of Managing Projects in Business.

34. Tikkanen, H., Kujala, J., \& Artto, K. (2007). The marketing strategy of a project-based firm: The Four Portfolios Framework. Industrial marketing management, 36(2), 194-205.

35. Vargo, S., \& Lusch, S. (2004). Evolving to a new dominant logic for marketing. Journal of Marketing, 68(1), 1-1 7. doi:10.1509/jmkg.68.1.1.24036.

36. Yeo, K.T., \& Ning, J. H. (2002). Integrating supply chain and critical chain concepts in engineerprocure-construct (EPC) projects. International Journal of Project Management, 20(4), 253-262.

37. Bushuyev, S., Bushuiev, D., \& Bushuieva, V. (2020, June). Modelling of Emotional Infection to the Information System Management Project Success. In International scientific-practical conference (pp. 341-352). Springer, Cham.

38. Bushuyev, S., Bushuieva, V., Onyshchenko, S., \& Bondar, A. (2021, January). Modeling the dynamics of information panic in society. COVID-19 case. In CEUR Workshop Proceedings (Vol. 2864).

39. Bondar, A., Bushuyev, S., Bushuieva, V., \& Onyshchenko, S. (2021). Complementary strategic model for managing entropy of the organization CEUR Workshop Proceedings, (Vol. 2851), 293-302.

40. Bushuyev, S., Babayev, I., Bushuiev, D., Bushuyeva, N., \& Babayev, J. (2021, February). Emotional Behavior in the» Infodemic vs. Panicdemic vs. Pandemic» modeling COVID-19. In ITPM (pp. 391400).

41. Bushuyev, S., Bushuiev, D., \& Bushuieva, V. (2020, September). Interaction Multilayer model of Emotional Infection with the Earn Value Method in the Project Management Process. In 2020 IEEE 15th International Conference on Computer Sciences and Information Technologies (CSIT) (Vol. 2, pp. 146-150). IEEE.

42. Bondar, A., Bushuyev, S., Bushuieva, V., Bushuyeva, N., \& Onyshchenko, S. (2020, September). ActionEntropy Approach to Modeling of 'Infodemic-Pandemic'System on the COVID-19 Cases. In Conference on Computer Science and Information Technologies (pp. 890-903). Springer, Cham.

43. Bushuyev, S., Babayev, J., Bushuiev, D., \& Kozyr, B. (2020, March). Emotional Infection of Management Innovation SMART Government Projects. In 2020 IEEE European Technology and Engineering Management Summit (E-TEMS) (pp. 1-5). IEEE. 